\title{
O sujeito-arquivista discursivizado em "Brazil, o filme"*
}

\author{
Jonathan Raphael Bertassi da Silva**
}

\begin{abstract}
Resumo: Nesse artigo, temos em vista a tensão entre apatia e engajamento vivida pelo sujeitoarquivista no filme Brazil (1985), dirigido pro Terry Gilliam. Para interpretar nosso corpus de pesquisa, nos pautamos no referencial teórico da Análise do Discurso de matriz francesa, a qual considera o sujeito em sua interpelação pela ideologia e o inconsciente, oferecendo deste modo bases para romper com o discurso dominante sobre uma "imparcialidade" supostamente desejável no exercício profissional da área. Em nosso trajeto, buscamos outros conceitos de "arquivo" e recuperamos as preocupações sobre o papel do arquivista pós-moderno tal como enunciadas pelo canadense Terry Cook.
\end{abstract}

Palavras-chave: arquivo; ideologia; sujeito; cinema; imaginário.

\section{Introdução}

Ao longo de nosso trabalho, buscamos interpretar a posição de sujeitoarquivista conforme inscrita pelo filme Brazil (1985), de Terry Gilliam. Por levar em conta a materialidade dos sentidos, o sujeito como interpelado pelo inconsciente e pela ideologia, julgamos que a Análise do Discurso francesa constitui-se como um campo teórico de contribuição apropriada para interpretação do filme, o qual se enquadra na abordagem desejada por representar os atuais dilemas do profissional da arquivística, entre manter postura apática frente aos registros ou seu potencial para modificar (ou sancionar) os embates sócio-históricos, rompendo com a postura indiferente e burocrática que apreendemos no senso comum sobre os arquivistas, tal como enunciam os textos do teórico canadense Terry Cook. Para realizar essa leitura do filme, buscamos recursos na literatura científica sobre o discurso não-verbal, além do conceito de "arquivo" pela ótica da $\mathrm{AD}$, que difere daquele observado nas Ciências da Informação. A partir da interpretação discursiva do corpus analisado, notamos a formação discursiva do sujeito-arquivista atravessada pelo inconsciente e pela ideologia, distanciando-se da concepção positivista do arquivo como espaço neutro de transmissão do conhecimento, ao mesmo tempo em que os postulados de Michel Foucault e Jacques Derrida sobre a noção de "arquivo" mostram-se válidos para a reavaliação do papel social do profissional da informação que a Arquivística vem buscando nas últimas décadas.

\section{Análise do discurso e discurso não-verbal}

Elegemos, como referencial teórico-metodológico para a pesquisa, a Análise do Discurso de filiação francesa. Para a $\mathrm{AD}$ não há sentidos literais, categóricos,

\footnotetext{
* Esse texto é um recorte do TCC "Informação em (dis)curso: inscrição de sentidos em Brazil, o filme” (2009).

** Mestrando na FFCLRP/USP. Bolsista FAPESP. Pesquisador do E-L@DIS - Laboratório Discursivo: sujeito, rede eletrônica e sentidos em movimento, da FFCLRP/USP. E-mail: cid_sem_registro@yahoo.com.br
} 
passíveis de uma decodificação unívoca pelo sujeito-leitor, como se esse processo estivesse desvinculado do contexto sócio-histórico. Muito pelo contrário: a $\mathrm{AD}$ vem justamente mostrar como tanto na função de autor quanto na de leitor, o sujeito inscreve significados eivados de historicidade. A ideologia se reflete, portanto, no processo da leitura, a qual tende sempre a ser plural e múltipla. Fundada nos anos 60 por Michel Pêcheux, a AD é uma disciplina criada a partir dos postulados de outros três domínios disciplinares: a Linguística, o Marxismo e a Psicanálise (MUSSALIM, 2000). A noção de discurso para a AD é entendida como objeto de investigação científica da disciplina, como "efeitos de sentido entre interlocutores" (PÊCHEUX, 1997), rompendo, portanto, com a definição do senso comum. O sentido das palavras não são transparentes nem literais em relação aos significantes (embora o sujeito tenha essa ilusão), não existem em si mesmos, mas são determinados pelas posições ocupadas no processo sócio-histórico, o palco da (re)produção das palavras no qual o sujeito está intrinsecamente ligado para fazer circular seus dizeres. "Onde está a linguagem está a ideologia" (ORLANDI, 2003, p. 34).

Visamos, assim, interpretar os sentidos sobre o não-verbal e sua relação com o discurso verbal. Para tanto, lançamos mão dos conceitos de teóricos da $\mathrm{AD}$ que mobilizam essa reflexão. A palavra pode falar da imagem, mas nunca revelar sua matéria visual. Em vista disso, a imagem não vale nem mil palavras, nem outro número qualquer. Na superposição do verbal, como ocorre com as legendas, a complexidade e polissemia das imagens é minimizada por um processo de interpretação uniforme e um sentido imposto que se pretende literal, reduzindo a imagem a um dado complementar, tirando dela a textualidade, o caráter de linguagem, apagada num elemento tornado visível (SOUZA, 2001). Ao invés de entender essa relação conflitante entre ambos, Neckel (2005) sugere a hipótese de verbal e não-verbal serem tratados como processos discursivos, às vezes pertencentes à mesma dimensão, e não como discursos em si. Desse modo, ambos poderiam estar em qualquer discurso - no caso do trabalho da autora, o Discurso Artístico. Com isso, a constituição do não verbal em enunciados imagéticos e gestuais é vista como processo e não produto.

\section{Sentidos sobre o sujeito-arquivista em "Brazil, o filme"}

No teor irônico e anárquico típico da obra de Gilliam (ex-integrante do grupo humorístico inglês Monty Python), observamos em Braz̧il material rico para análise do papel do profissional da informação no que tange à sua responsabilidade social, bem como os perigos que residem na crença da "impessoalidade" supostamente ideal para o trabalho com os registros institucionais. Se a visão comum sobre o arquivista é a do profissional passivo, que se limita a tratar de modo neutro e objetivo os registros, quase como uma espécie de antítese do poder (SCHWARTZ; COOK, 2002), em Brąil vemos justamente o oposto: a inscrição da participação (nem sempre consciente) do arquivista no contexto social, às vezes pró e outras contra o status vigente.

O referencial teórico da Análise do Discurso, por levar em conta tanto a ideologia quanto o inconsciente e os embates de formações discursivas que se dão no mesmo sujeito (alegoria inscrita com riqueza de nuances na trajetória do protagonista Sam Lowry, no filme), daí o interesse em usar esse referencial para interpretar as cenas de Braz̧il, evidenciando as relações de poder nas quais a instituição arquivística está imersa, bem como o papel ético do sujeito-arquivista no âmbito do Estado. Percebe-se, 
no filme, que tanto na realidade distópica quanto nos sonhos escapistas do protagonista, o discurso se torna cada vez mais confuso no desenrolar da projeção, levanto à tona o cruzamento de um emaranhado de vozes que escapam ao controle do sujeito-arquivista, o qual se supõe dono de seus sentidos. Daí a dicotomia entre realidade amarga/sonho redentor, inicialmente separados um do outro, trocarem de lugar constantemente numa (con)fusão que mergulha o sujeito em desejos e práticas contraditórias simultâneas que lhe escapam à compreensão, até culminar no desfecho sombrio que encerra Brazil.

\section{Referências}

MUSSALIM, F. A análise do discurso. In: MUSSALIM, F. ; BENTES, A. C. (orgs.). Introdução à lingüística: domínios e fronteiras. São Paulo: Cortez, 2000.

NECKEL, N. R. M. Análise de Discurso e o discurso artístico. In: SEAD - Anais eletrônicos do Seminário de Análise do Discurso, 2, 2005, Porto Alegre, RS: UFRGS, 2005.

ORLANDI, E. P. A linguagem e seu funcionamento: as formas do discurso. 4. ed. Campinas, SP: Pontes, 2003.

PÊCHEUX, M. Semântica e discurso: uma crítica à afirmação do óbvio. 3. ed. Campinas, SP: Editora da UNICAMP, 1997. (Coleção Repertórios)

SCHWARTZ , J. M.; COOK, T. Archives, records, and power: the making of modern memory. Archival Science, Netherlands, v. 2, 2002, p. 1-19.

SOUZA, T. C. C. A análise do não verbal e os usos da imagem nos meios de comunicação. Ciberlegenda, n. 6, 2001. 